\title{
Klimaendringer gir helseskader
}

\author{
Den globale oppvarmingen er den største trusselen mot global helse i det 21. århundre. \\ Som leger med kunnskap om dette har vi et spesielt ansvar for å hindre at situasjonen utvikler seg.
}

Legeforeningen har de siste par år tatt flere prisverdige initiativer med tanke på klima og helse $(1,2)$. Foreningen har nedsatt en arbeidsgruppe for denne problematikken og vil bidra med kompetanse og synliggjøring overfor myndigheter og andre. Det anbefales også å arbeide for mer forskning om klimarelaterte helsekonsekvenser og innføre undervisning om temaet i medisinske fag. Også Verdens legeforening har engasjert seg i saken og vedtok i oktober 2009 en offensiv deklarasjon om klima og helse (3). I tillegg til å foreslå forebyggende og andre tiltak anbefaler organisasjonen at leger som enkeltmennesker går inn for å minimalisere egne klimagassutslipp.

The Lancet kommenterte nylig saken (4) i relasjon til at tidsskriftet i desember publiserte en serie artikler om klima og helse og i juni en grundig oversiktsartikkel om hvilke helseeffekter som kan forventes på grunn av klimaendringene (5). I artikkelen omtales den globale oppvarmingen som den største trusselen mot global helse i det 21. hundreåret. Effektene vil først og kraftigst ramme fattige grupper som selv har bidratt minst til klimaendringene. Alvorlige helsekonsekvenser kan alt nå beskrives ganske godt: sykdom på grunn av sviktende vannforsyning, tørke og dårligere forhold for matproduksjon, ekstremt vær, hete, flom, havstigning og migrasjon. Det er enighet om at disse konsekvensene kan bli meget alvorlige selv om vi ikke kan forutsi nøyaktig når og hvor ulike effekter vil gjøre seg gjeldende.

Helsearbeidere og helsesystemer i fattige land kan bare i liten grad bidra til å redusere omfanget av helseeffektene av et varmere klima. Derfor har vi som helsearbeidere som kjenner de alvorlige konsekvensene, et primæransvar for å gjøre alt vi kan for å forebygge skadene. Klimaendringene og helseeffektene av disse kan bare i liten grad begrenses om vi ikke raskt nok greier å legge til rette for en samfunnsutvikling der vi gradvis gjør oss uavhengige av fossilt brensel.

Om verdens ledere ikke i løpet av få år setter i verk atskillig sterkere tiltak mot utslipp av klimagasser enn det som ble antydet under klimamøtet i København, er det stor fare for at vi vil gå mot en temperaturøking på $3-4^{\circ}(6)$. Dette er langt over hva som beskrives som et «vippepunkt» for irreversible klimaendringer og som vil resultere i meget alvorlige konsekvenser (7). Mange mener også at det offisielle internasjonalt aksepterte målet om en stabilisering av temperaturen på $2^{\circ}$ over forindustrielt nivå er for høyt, og at alt over $1,5^{\circ}$ stigning gir stor risiko for alvorlige effekter (6).

Leger har også tidligere stått i spissen for å argumentere for nødvendigheten av å forebygge alvorlige helseeffekter av årsaker der vi vet vi kan oppnå lite med behandlende tiltak. Fredsprisvinneren International Physicians for the Prevention of Nuclear War (IPPNW) har betydd mye for arbeidet mot spredning av atomvåpen $\mathrm{og}$ for at en atomvåpenfri verden nå er på den politiske dagsordenen. Klimakrisen kan få konsekvenser for livet på jorden som i omfang kan sammenliknes med bruk av atomvåpen. Men til forskjell fra effekten av bruk av atomvåpen vil helseskader på grunn av klimaendringene utvikle seg over et langt tidsperspektiv, affisere forskjellige befolkningsgrupper i ulik grad og vil fortsatt i mange tiår i relativt liten grad affisere rike land som primært sitter med nøkkelen til løsningene.

Forfatterne av Lancet-artikkelen etterlyser bedre dokumentasjon også av de meget alvorlige helsemessige konsekvensene av en $3-4^{\circ}$ temperaturstigning, noe som de mener vil vise nødvendigheten av å iverksette øyeblikkelige og drastiske tiltak for å redusere klimagassutslippene (5). En nøyaktig beskrivelse av effektene vil kunne ha samme virkningsom da de medisinske konsekvensene av bruk av atomvåpen ble beskrevet: De fleste vil forstå at helseskadene på grunn av sterke klimaendringer er uakseptable. Med klar kunnskap om dette har vi et moralsk ansvar for å hindre at en slik situasjon får utvikle seg.

Representanter for en rekke innflytelsesrike organisasjoner for leger, både fra rike og fattige land skriver i en kommentar: «As leaders of physicians across many countries, we call on doctors to demand that their politicians listen to the clear facts that have been identified in relation to climate change and act now to implement strategies that will benefit the health of communities worldwide» (8).

Kanskje leger som er engasjert i forebygging av helseskader av klimaendringer skulle ta lærdom av den internasjonale gruppen for leger mot atomvåpen (IPPNW) og etablere en organisasjon: «International Physicians for the Prevention of Climate Change»? I England finnes allerede et godt etablert «Climate and Health Council», et nettverk med internasjonale forgreninger (9). Det kunne også ha stor betydning om mange leger engasjerer seg i eksisterende nettverk som arbeider med denne problematikken (9-12).

\section{Gunnar Kvåle}

gunnar.kvale@cih.uib.no

Senter for internasjonal helse

Universitetet i Bergen

Postboks 7804

5020 Bergen

Oppgitte interessekonflikter: Ingen

Litteratur

1. Janbu T. Fra presidenten: Klima og helse. Tidsskr Nor Legeforen 2008; 128: 2237

2. Braaten KE. Resept for en frisk planet. Tidsskr Nor Legeforen 2010; 130: 189.

3. World Medical Association. Declaration of Dehli on Health and Climate Change www.wma.net/en/ 30publications/10policies/c5/index.html (9.2.2010). The climate dividend. Lancet 2009; 374: 1869-70.

5. Costello A, Abbas M, Allen A et al. Managing the health effects of climate change. Lancet 2009; 373 $1693-1733$

6. Allison I, Bindoff N, Bindschadler R et al. The Copenhagen diagnosis. Updating the world on the latest climate science. The University of New South Wales Climate Change Research Centre, Sydney, Australia, 2009 www. copenhagendiagnosis.com/ (8.3.2010).

7. Hansen J. Storms of my grandchildren. Boomsbury, New York, 2009.

8. Lim V, Stubbs JW, Nahar N et al. Politicians must heed health effects of climate change. Lancet 2009; 374: 973

9. Climate and Health Council. www. climateandhealth.org/ (8.3.2010).

10. Concerned Scientists - Norway. www.cs-n.org/ (3.3.2010).

11. Norsk klimanettverk. www.norskklimanettverk.no/ (3.3.2010).

12. 10: 10 Norge. www. 1010 norge.no/ (3.3.2010).
«Klimaendringene og helseeffektene av disse kan bare i liten grad begrenses om vi ikke raskt nok greier å legge til rette for en samfunnsutvikling der vi gradvis gjør oss uavhengige av fossilt brensel»
Manuskriptet be mottatt 14.2. 2010 og godkjent 25.2. 2010. Medisinsk redaktør Anne Kveim Lie. 